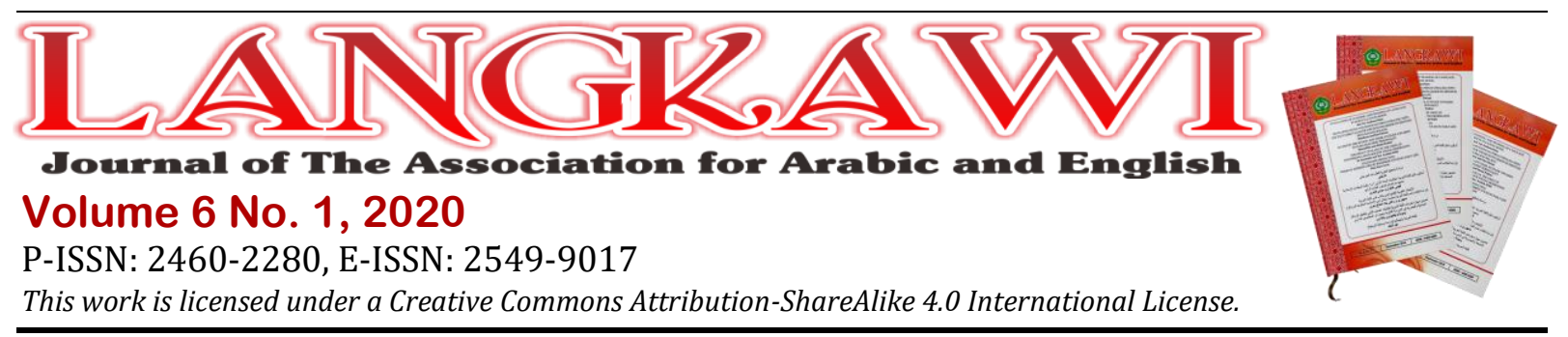

\title{
Improving the Students' English Skills through Online Activities in Moodle Platform
}

\author{
Didik Hariyadi Raharjo ${ }^{1^{*}}$, Ilza Mayuni ${ }^{2}$, Emzir $^{3}$ \\ ${ }_{1}^{1}$ Universitas Negeri Jakarta, Indonesia. Email: didikhariyadi_pb14s3@mahasiswa.unj.ac.id \\ ${ }^{2}$ Universitas Negeri Jakarta, Indonesia. E-mai: ilzamayuni@unj.ac.id \\ 3Universitas Negeri Jakarta, Indonesia. E-mail: emzir.unj@unj.ac.id \\ *corresponding author
}

ARTICLE INFO
Keywords:
Moodle; English skills;
Fully Online Learning
How to cite:
Raharjo, D. H., Mayuni,
I., Emzir, E. (2020).
Improving the Students'
English Skills through
Online Activities in
Moodle Platform.
Langkawi: Journal of The
Association for Arabic and
English, 6(1), 55-70.
DOI:
http:/ /dx.doi.org/10.31
332/lkw.v6i1.1846

\section{ARTICLE INFO}

Keywords:

Moodle; English skills;

How to cite:

Raharjo, D. H., Mayuni, I., Emzir, E. (2020). Improving the Students

Moodle Platform. Langkawi: Journal of The Association for Arabic and DOI: 332/lkw.v6i1.1846

\begin{abstract}
This research was aimed to determine the effectiveness of online instructional material model for EFS courses developed through Moodle for Secretarial Academy (ASTRI) of Budi Luhur students when compared to the existing EFS instructional material. This qualitative research conducted in the second semester of 2007/2008 academic year. Meanwhile the data sources used in this study were respondents consisting of 48 ASTRI Budi Luhur students as well as documents consisting of observation guidelines and post test results. The students were divided into 2 classes, namely $B A$ and $B B$ classes. $B A$ class is treated as an experimental class while $B B$ class is treated as a control class. This experiment was carried out for 7 times fully online learning with synchronous learning method. In analyzing the data collected, the researchers used T-Test to find out the effectiveness of EFS instructional material through Moodle. Based on the results of the post test conducted, EFS instructional material through Moodle had been proven to be able to improve four english skills which include listening, reading, speaking and writing to the students of ASTRI Budi Luhur Jakarta.
\end{abstract}

\section{Introduction}

English was very important in the business and industrial world. Most companies (45.2\%) required that their job applicants were proficient in English and could use them to communicate. In addition, there were several industries that required job applicants to master English language skills passively (7.8\%), both verbally $(23.5 \%)$ and in writing $(23.5 \%)$ (Yuliah, Bakhti and Setyawan, 2016). There were five types of work groups that require applicants to master English, including; administrative and management work groups, sales and marketing, education, communication, and other types of occupations. In the field of administration and management, English were the language of international business, therefore, it was very important for a secretary to be able to communicate effectively in English (Eamjoy, 2015). Furthermore, in the field of administration and management, English is an international business language, therefore it is very important for a secretary to be able to communicate effectively in English (Eamjoy, 2015).

One of the jobs in administration was the secretary. In this case, English was very important for a secretary to complete various tasks and to communicate with colleagues, superiors and corporate clients. Nowadays, secretaries play a very 
important role in almost all large-scale multinational companies (Strevens, 1993). Based on this phenomenon, the Secretarial Academy (ASTRI) of Budi Luhur believed that English was one of the main skills that had to be mastered and learned by the students. In the applied curriculum, English courses had a large number of a total of 18 credits for 5 courses.

However, the facts said that the English skills of ASTRI Budi Luhur students needed to be further developed. Based on the TOEIC test score data conducted in 5 years, it showed that almost of ASTRI Budi Luhur students scored 300-500. And, only $25.6 \%$ of students scored more than 500 . It showed that they could get basic proficiency certificate and were considered capable to work in an international company. With the condition of the student's English proficiency, it would directly affect the waiting time and the type of company and the scale of the company where they will work.

Based on the preliminary observations that the researchers had done, the low English proficiency of ASTRI Budi Luhur students was also influenced by the conditions of existing English instructional material in ASTRI Budi Luhur. Ideally, a good English instructional material would help the students to develop their four english skills. Instructional material referred to everything that was used by instructors or learners to facilitate learning (Tomlinson, 2011); Richards \& Schmidt, 2010). Meanwhile, (Richards \& Rodgers, 2001) defined instructional material as everything that functions primarily to supplement of teaching. Instructional material was the main component in language learning. Based on this opinion, instructional material could be interpreted as a main component and complementary components of a learning process. Porter \& Brown, (1997) described instructional material as a systematic description of the techniques and exercises that will be used in classroom teaching. It had to be able to facilitate students and instructors. It could be in the form of linguistic, visual, auditory, or kinesthetic materials. Instructional material could be presented in printed form (textbooks, workbooks, photocopied leaflets, etc.), audio or video formats, CD-Roms, via the internet or through performance or displays.

Based on the problems faced and all the potential possessed by ASTRI Budi Luhur, the researchers developed a instructional material for EFS course through Moodle. It was fully online instructional material or e-learning instructional material where all meetings were delivered via online / e-learning. Genova (2019) stated that e-learning as a new environment in which both instructors and learners used it to interact with each other. Information technology could be used to support teaching and enhanced learning, for learning media, to collaborate and to make instructional material. In line with this opinion, Dabbagh and Ritland (2005) defined e-learning as an open and distributed learning environment that used pedagogical equipment, activated by internet and web-based technology, to facilitate learning to build knowledge through meaningful actions and interactions. Clark and Mayer (2012) stated that e-learning as teaching delivered through digital equipment such as computers or mobile devices intended to support learning.

Furthermore, Dabbagh and Ritland (2005) stated that e-learning learning consists of a series of interrelated components. The first component was infrastructure such as computers (service and client), internet network or intranet 
multimedia equipment and teleconference equipment. The second component was the e-learning system and application. This component was software that virtualizes the learning process. This software system was known as Learning Management System (LMS) such as Elisa, Moodle, Class Server and so on. The last component was e-learning content. This content could be in the form of text-based content, webbased content and multimedia-based content.

Online learning models had different types, those were synchronous learning and asynchronous learning. Synchronous Learning was a learning process carried out by lecturers and learners at the same time to enable direct interaction in the learning process either through the internet or intranet. Meanwhile, the asynchronous learning method did not depend on time, where all users (learners and lecturers) can access the system and communicate according to their own time. Furthermore, Noirid, Surachet; Srisa-ard, (2007) classifies the continuum of online learning in three models of online learning delivery namely; adjuct, mixed / blended and fully online. The adjunct model was used to support the face-to-face learning system in the classroom. The mixed/blended model placed e-learning into an inseparable part of classroom learning. Meanwhile, the fully online model was used for the entire learning process starting from the delivery of learning materials, learning interactions, and evaluation of learning (See Figure 1).

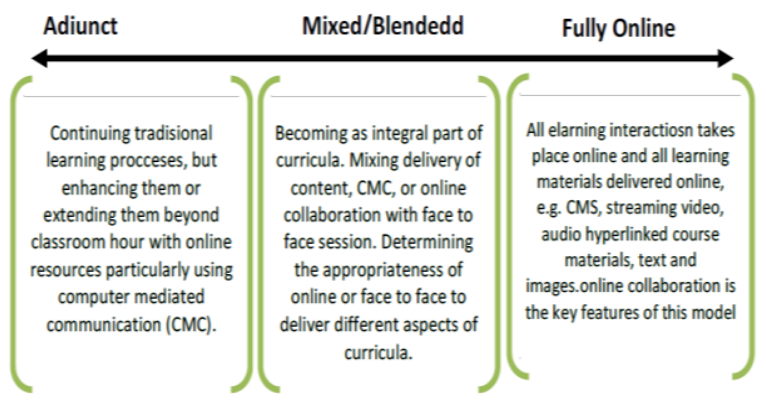

Figure 1: E-Learning Continum

As stated before that instructional material used in this research was developed through Moodle. Moodle is an abbreviation of Modular ObjectOriented Dynamic Learning Environment developed by Martin Dougiamas (Darmawan, 2014). Meanwhile Stanford, (2009) stated that Moodle was also commonly referred to as a Learning Management System (LMS) or Course Management System (CMS). Both CMS and LMS can be used for online learning systems. Meanwhile Lesmana, Susanto and Mufti (2013) defined Moodle as a software package produced for internet and web-based learning activities. Wade (2018) believed that Moodle was an open source learning platform that enables a multimedia approach to teaching.

In line with this opinion, Alkoumani and Elkalimi, (2015) believed that Moodle could help the teachers to facilitate online learning and to create an interactive learning environment. (Bader Al Bataineh, Abdullah Ahmed Banikalef, \& H. Albashtawi, 2019) stated that Moodle allowed the teachers, administrators, and learners to form personalized learning arrangements. Moodle provides a variety of modules to help teachers and learners navigate and complete learning. Furthermore, Stanford, (2009) summarized all learning activities of 4 English language skills as shown in table 1. 
Didik Hariyadi Raharjo, Ilza Mayuni, Emzir: Improving the Students' English Skills...

Table 1: Listening Activities in Moodle

\begin{tabular}{|c|c|c|c|}
\hline Activities & Aim & Modules & $\begin{array}{c}\text { Extra } \\
\text { Programs }\end{array}$ \\
\hline $\begin{array}{l}\text { Activity 1: } \\
\text { Using Forum to } \\
\text { motivate students }\end{array}$ & $\begin{array}{l}\text { Help motivate students } \\
\text { by discussing what } \\
\text { recordings to listen to }\end{array}$ & Forum & Mediacenter \\
\hline $\begin{array}{l}\text { Activity 2: } \\
\text { Using Mindmap to } \\
\text { anticipate content of a } \\
\text { recording }\end{array}$ & $\begin{array}{l}\text { Help students think of } \\
\text { likely content of a } \\
\text { recording they are about } \\
\text { to hear }\end{array}$ & - & Mindmap \\
\hline $\begin{array}{l}\text { Activity 3: } \\
\text { Investigating texts } \\
\text { using Quiz }\end{array}$ & $\begin{array}{l}\text { Using quiz to } \\
\text { investigate texts }\end{array}$ & Quiz & - \\
\hline $\begin{array}{l}\text { Activity 4: } \\
\text { Prediction activity } \\
\text { using Lesson }\end{array}$ & $\begin{array}{l}\text { Help students predict a } \\
\text { recorded text }\end{array}$ & Lesson & - \\
\hline $\begin{array}{l}\text { Activity 5: } \\
\text { Reviewing recordings } \\
\text { using Choice }\end{array}$ & $\begin{array}{l}\text { Using polls to vote on a } \\
\text { recording }\end{array}$ & Choice & - \\
\hline $\begin{array}{l}\text { Activity 6: } \\
\text { Reviewing recordings } \\
\text { using Questionnaire }\end{array}$ & $\begin{array}{l}\text { Get students to think } \\
\text { about recordings } \\
\text { through an evaluation } \\
\text { questionnaire }\end{array}$ & $\begin{array}{l}\text { Questionnaire } \\
\text { add-on }\end{array}$ & - \\
\hline $\begin{array}{l}\text { Activity 7: } \\
\text { Developing students' } \\
\text { critical faculties through } \\
\text { online discussion about } \\
\text { recordings they've } \\
\text { listened to }\end{array}$ & $\begin{array}{l}\text { Stimulate online } \\
\text { discussion about } \\
\text { recordings that students } \\
\text { have listened to }\end{array}$ & Forum & Mediacenter \\
\hline
\end{tabular}

Listening activities could be done through 7 activities with different objectives and several modules such as; forum, quiz, lesson or other with the help of some extra programs such as mediacenter, mindmap and so on. In connection with listening activities through Moodle, the results of a study conducted by Cedar (2013) showed that there was an increase in post test scores compared with pre test scores in listening classes using Moodle. Cordova \& Dechsubha, (2018) found that through Moodle, listening skills in ESP classes at Vongchavalitkul University students had increased. In addition, the research also proved that technology, online and mobile applications combined with collaboration and learner independence played an important role in improving their listening skills.

Speaking had more activities through Moodle than reading and listening. It could be done through 9 activities with different objectives and several modules such as; chat, quiz, database or other activities with the help of some extra programs such as: NanoGong and Audacity. (See table 2). Unfortunately, Moodle did not yet provide a module that could be used to record audio to facilitate the student speaking activities for free. Speaking activities could be facilitated by using other 
tools such as NanoGong and Audacity. To facilitate speaking activities in the developed EFS instructional material, the researchers used the modules available in Moodle to upload speaking materials, but the evaluation activities were carried out using telephone and e-mail devices. The telephone was used to provide an evaluation of secretarial themes carried out with this tool. Considering that there were a lot of secretarial works done by telephone. For other activities, the students could record the results of their work using their mobile telephone devices and then sended them via e-mail to the lecturer.

Table 2: Speaking Activities in Moodle

\begin{tabular}{|c|c|c|c|}
\hline Activities & Aim & Modules & $\begin{array}{c}\text { Extra } \\
\text { Programs }\end{array}$ \\
\hline $\begin{array}{l}\text { Activity 1: } \\
\text { Helping students improve } \\
\text { pronunciation using the } \\
\text { Forum module }\end{array}$ & $\begin{array}{l}\text { Provide oral feedback on } \\
\text { students' pronunciation }\end{array}$ & Forum & - \\
\hline $\begin{array}{l}\text { Activity 2: } \\
\text { Creating a word stress } \\
\text { matching activity using the } \\
\text { Quiz module }\end{array}$ & $\begin{array}{l}\text { Help students identify } \\
\text { sounds }\end{array}$ & Quiz & NanoGong \\
\hline $\begin{array}{l}\text { Activity 3: } \\
\text { Adding a sound extension } \\
\text { to vocabulary lists }\end{array}$ & $\begin{array}{l}\text { Help students practice the } \\
\text { pronunciation of words in } \\
\text { their vocabulary lists }\end{array}$ & Database & NanoGong \\
\hline $\begin{array}{l}\text { Activity 4: } \\
\text { Using OUwiki to help } \\
\text { students learn by repeating }\end{array}$ & $\begin{array}{l}\text { Help students practice } \\
\text { speaking by listening and } \\
\text { repeating }\end{array}$ & OUwiki & NanoGong \\
\hline $\begin{array}{l}\text { Activity 5: } \\
\text { Dialog Minus One-helping } \\
\text { students build dialogs using } \\
\text { a podcast }\end{array}$ & $\begin{array}{l}\text { Help students participate } \\
\text { in a dialog }\end{array}$ & Mediacenter & Audacity \\
\hline $\begin{array}{l}\text { Activity 6: } \\
\text { Preparing for class speaking } \\
\text { practice using a Wiki }\end{array}$ & $\begin{array}{l}\text { Help students prepare } \\
\text { contents for later class } \\
\text { speaking activities }\end{array}$ & $\begin{array}{l}\text { Wiki atau } \\
\text { Ouwiki } \\
\text { (opsional) }\end{array}$ & - \\
\hline $\begin{array}{l}\text { Activity 7: } \\
\text { Preparing a class discussion } \\
\text { using Chat }\end{array}$ & $\begin{array}{l}\text { Help students prepare } \\
\text { vocabulary and points of } \\
\text { view for a face-to-face } \\
\text { discussion }\end{array}$ & Chat & - \\
\hline $\begin{array}{l}\text { Activity 8: } \\
\text { Producing presentations } \\
\text { using an OUblog }\end{array}$ & $\begin{array}{l}\text { Get students to present } \\
\text { monologs in their Moodle } \\
\text { blogs }\end{array}$ & OUBlog & NanoGong \\
\hline $\begin{array}{l}\text { Activity 9: } \\
\text { Presenting a monolog using } \\
\text { the Quiz module }\end{array}$ & $\begin{array}{l}\text { Help students produce } \\
\text { monologs for assessment }\end{array}$ & Quiz & NanoGong \\
\hline
\end{tabular}

Reading activities through Moodle could be done through 7 activities with different objectives and several modules such as; lesson, hot potatoes, questionnaire or other activities with the help of some extra programs such as NanoGong and Audacity. 
(See table 3). The results of the research conducted by Nurhayati, (2013) showed that reading instructional material through Moodle that was developed could be used well and could improve the students' reading mastery. The students also gave a very positive attitude towards the product being developed. In addition, this research proved that the application of a website could improve students' reading competence in terms of content, organization, vocabulary, language use, and mechanics and could increase their motivation in using e-learning as an alternative medium for learning.

Table 3: Reading Activities in Moodle

\begin{tabular}{|c|c|c|c|}
\hline Activities & Aim & Modules & $\begin{array}{c}\text { Extra } \\
\text { Programs }\end{array}$ \\
\hline $\begin{array}{l}\text { Activity 1: } \\
\text { Using Forum for a book } \\
\text { discussion }\end{array}$ & $\begin{array}{l}\text { Help motivate students } \\
\text { by discussing what } \\
\text { books to read }\end{array}$ & Forum & - \\
\hline $\begin{array}{l}\text { Activity 2: } \\
\text { Using Web pages to read } \\
\text { and listen }\end{array}$ & $\begin{array}{l}\text { Help students follow } \\
\text { text by allowing them to } \\
\text { read and listen } \\
\text { simultaneously }\end{array}$ & $\begin{array}{l}\text { Moodle Web } \\
\text { page or Book }\end{array}$ & $\begin{array}{c}\text { NanoGong } \\
\text { or } \\
\text { Audacity }\end{array}$ \\
\hline $\begin{array}{l}\text { Activity 3: } \\
\text { Using Choice for voting on } \\
\text { texts }\end{array}$ & $\begin{array}{l}\text { Using polls to vote on a } \\
\text { text }\end{array}$ & Choice & - \\
\hline $\begin{array}{l}\text { Activity 4: } \\
\text { Using Blog to explore texts }\end{array}$ & $\begin{array}{l}\text { Investigate the meaning } \\
\text { of interesting words } \\
\text { through their context }\end{array}$ & $\begin{array}{c}\text { Blog and Blog } \\
\text { Tags block }\end{array}$ & - \\
\hline $\begin{array}{l}\text { Activity 5: } \\
\text { Using Questionnaire to } \\
\text { explore texts }\end{array}$ & $\begin{array}{l}\text { Get students to think } \\
\text { about texts through a } \\
\text { questionnaire }\end{array}$ & $\begin{array}{l}\text { Questionnaire } \\
\text { add-on }\end{array}$ & - \\
\hline $\begin{array}{l}\text { Activity 6: } \\
\text { Using Hot Potatoes to } \\
\text { investigate texts }\end{array}$ & $\begin{array}{l}\text { Help students } \\
\text { understand texts better }\end{array}$ & Hot Potatoes & - \\
\hline $\begin{array}{l}\text { Activity 7: } \\
\text { Using Lesson for text } \\
\text { prediction }\end{array}$ & $\begin{array}{l}\text { Help students predict } \\
\text { text }\end{array}$ & Lesson & - \\
\hline
\end{tabular}

Writing has the most variety of activities. It had 12 activities that could be done through Moodle. These activities could be done with several modules such as; chat, forum, wiki, glossary or other activities with the help of some extra programs. (See table 4). Robertson, (2008) stated that by applying Moodle into writing composition learning, lecturers got various benefits in the fields of organization, implementation, distribution, communication, and assessment. First, all instructional material and learning resources could be placed in one location and could be easily revised and restructured. Second, by utilizing all the menus contained in Moodle, the lecturer could quickly create interesting projects and assignments and motivate learners. Third, teachers could easily distribute 
instructional material. Fourth, Moodle managed all communication between instructors and learners individually or in groups. Finally, Moodle could save and display assessment notes from students.

Table 4: Writing Activities in Moodle

\begin{tabular}{|c|c|c|c|}
\hline Activities & Aim & Modules & $\begin{array}{c}\text { Extra } \\
\text { Programs }\end{array}$ \\
\hline $\begin{array}{l}\text { Activity 1: } \\
\text { Raising awareness of text } \\
\text { structure using Quiz }\end{array}$ & $\begin{array}{l}\text { Raise students' awareness } \\
\text { of how certain texts are } \\
\text { ordered }\end{array}$ & Quiz & - \\
\hline $\begin{array}{l}\text { Activity 2: } \\
\text { Practicing register using } \\
\text { Lesson }\end{array}$ & $\begin{array}{l}\text { Raise students' awareness } \\
\text { of register and develop } \\
\text { their ability to manipulate } \\
\text { it in their writing. }\end{array}$ & Lesson & - \\
\hline $\begin{array}{l}\text { Activity 3: } \\
\text { Using Mindmap to } \\
\text { brainstorm writing } \\
\text { assignments }\end{array}$ & $\begin{array}{l}\text { Help students explore and } \\
\text { organize a range of ideas } \\
\text { which they can use }\end{array}$ & - & Mindmap \\
\hline $\begin{array}{l}\text { Activity 4: } \\
\text { Producing effective } \\
\text { personal profiles }\end{array}$ & $\begin{array}{l}\text { Help students write } \\
\text { engaging personal profiles }\end{array}$ & $\begin{array}{l}\text { Personal } \\
\text { Profile }\end{array}$ & - \\
\hline $\begin{array}{l}\text { Activity 5: } \\
\text { Using Journal for reflective } \\
\text { or private writing }\end{array}$ & Help students keep a diary & Journal & - \\
\hline $\begin{array}{l}\text { Activity 6: } \\
\text { Using a Blog or Web page } \\
\text { for creative writing }\end{array}$ & $\begin{array}{l}\text { Help students write } \\
\text { creatively }\end{array}$ & $\begin{array}{c}\text { Blog, } \\
\text { OUblog }\end{array}$ & - \\
\hline $\begin{array}{l}\text { Activity 7: } \\
\text { Writing encyclopedia } \\
\text { entries using Glossary }\end{array}$ & $\begin{array}{l}\text { Help students improve } \\
\text { their ability to write clear } \\
\text { descriptions }\end{array}$ & Glossary & - \\
\hline $\begin{array}{l}\text { Activity 8: } \\
\text { Promoting fluency writing } \\
\text { using Chat }\end{array}$ & $\begin{array}{l}\text { Help students improve } \\
\text { their ability to get their } \\
\text { meaning across quickly }\end{array}$ & Chat & - \\
\hline $\begin{array}{l}\text { Activity 9: } \\
\text { Using Assignment to } \\
\text { submit and evaluate semi- } \\
\text { authentic writing }\end{array}$ & $\begin{array}{l}\text { Provide students with } \\
\text { feedback on written } \\
\text { assignments }\end{array}$ & Assignment & - \\
\hline $\begin{array}{l}\text { Activity 10: } \\
\text { Writing a slideshow } \\
\text { commentary using Forum }\end{array}$ & $\begin{array}{l}\text { Get students writing about } \\
\text { a set of images }\end{array}$ & Forum & - \\
\hline $\begin{array}{l}\text { Activity 11: } \\
\text { Summarizing RSS news } \\
\text { items }\end{array}$ & $\begin{array}{l}\text { Help students improve } \\
\text { each other's writing }\end{array}$ & $\begin{array}{l}\text { RSS block } \\
\text { dan forum }\end{array}$ & - \\
\hline $\begin{array}{l}\text { Activity 12: } \\
\text { Collaborative writing } \\
\text { using Wiki }\end{array}$ & $\begin{array}{l}\text { Help students write } \\
\text { different parts of a writing } \\
\text { project }\end{array}$ & Wiki & - \\
\hline
\end{tabular}


This research was conducted in the English for Secretary (EFS) course. EFS was one of the compulsory subjects that must be attended by ASTRI Budi Luhur students. This course was intended to equip students with English skills to complete secretarial task. As stated by Toselli and Milan (2006) that English for Secretary as learning English which was designed to meet the needs of secretaries who carry out administrative tasks in English both verbally and in writing. The Secretary was an assistant leader in starting and completing a job. The Secretary was expected to be able to help overcome busyness and solve difficulties, encourage the leadership, simplify the way the work was completed, and speed up the process of completing work so that the expected results can be achieved (Secretan, 1996).

EFS was specifically intended to provide knowledge about how to complete secretarial tasks. Nuraeni (2008) divided secretarial tasks into three types, namely, (1) routine tasks; (2) instructional task and (3) creative task. Routine tasks were general tasks that were done almost every day without waiting for instructions from the superiors in accordance with those that have been applied in the description of their duties. Instructional tasks carried out every day by the secretary, but these were based on instruction from the superiors. Creative tasks arised with the initiative of a secretary and were carried out so that the assistance given to the leadership could be useful and very helpful.

Several researches about the effectiveness of using Moodle in learning English had been conducted. One of them was conducted by (Wade, 2018). Based on the results of his research, it can be concluded that the combination of traditional learning and virtual classes by using Moodle in English for Specific Purposes (ESP) in Cagliary (Italy) enabled the students to move flexibly and could acquire language skills as success in learning. Meanwhile, Gluchmanova, (2017) found that the students got more motivation when they learned English using Moodle. Furthermore, Moodle could create not only independent students but also independent workers. This was because all activities in Moodle-based instructional material require students to work independently. Cordova \& Dechsubha, (2018) found that the students' post test results in listening learning using Moodle showed a significant improvement when compared to the average scores on the post test. In addition, the students also gave very positive feedback on learning by using Moodle.

In this research, the researchers aimed to find out the effectiveness of instructional material for EFS courses. Instructional material used are online instructional material that are delivered in full online learning. This instructional material was the main instructional material used in EFS courses. This instructional material was developed in the form of synchronous learning so that students can access lectures from where they were and they still be able to interact with lecturers and other students through the chat menus and forums that have been provided. With various menus provided by Moodle, lecturers could use it to upload material in the form of text, audio, video and images to make it easy for students to understand the material provided. This research was aimed to determine the effectiveness of online instructional material model for EFS courses developed through Moodle for ASTRI Budi Luhur students when compared to the existing EFS instructional material 


\section{Method}

This research was conducted at Secretarial Academi (ASTRI) of Budi Luhur located in Jl. Ciledug Raya, Petukangan Utara, South Jakarta. This research was aimed to improve the four English skills of ASTRI Budi Luhur Jakarta students by using online instructional material through Moodle for EFS courses. This was a quantitative research where most of the data in the form of student test scores. The method used in this research was experiment. Experiment was a practical way to learn something by changing conditions and observing their effects on other things. The aim is to determine the effect or cause and effect relationship by comparing the results of the experimental group that was given treatment with a control group that was not given treatment (Arifin, 2012).

Meanwhile the data sources used in this study were respondents consisting of 48 female ASTRI Budi Luhur students. Data collected by test method. The test was used twice, those were pre-test and post-test in large groups. Pretest was done before students took EFS learning through Moodle. While Postest was conducted after students got EFS learning with Moodle. The form of the questions from both tests was essay.

To find out the effectiveness of EFS instructional material through Moodle, it was done by t-test. To find out the homogeneity of the data in this study was carried out using the F-test. Meanwhile, to determine the normality of the data carried out on the experimental class and control class data using the Lilliefors test. In the posttest, both students from the experimental class and the control class are given the same English proficiency test.

Table 5: Method of the Research

\begin{tabular}{cclc}
\hline Approach & Method & \multicolumn{1}{c}{ Data Source } & Data Analysis \\
\hline Quantitative & Experiment & 1. Respondents: & 1. Effectiveness: T-Test \\
& & - Students (48 female & 2. Homogeneity: F-test \\
& & students) & 3. Normality: Lilliefors \\
- Lecturer (1 male & test \\
& & lecturer $)$ & \\
& 2.Document & \\
& - Observation guideline & \\
& - Post test result & \\
\hline
\end{tabular}

3. Findings and Discussion

This section is the most important section of your article. The analysis or results of the research should be clear and concise. The results should summarize (scientific) findings rather than providing data in great detail. Please highlight differences between your results or findings and the previous publications by other researchers.

\subsection{Findings}

To find out the effectiveness of Moodle instructional material, the researchers conducted an experiment involving 48 students of ASTRI Budi Luhur Jakarta, which was divided into 2 classes, namely BA and BB classes. BA class is treated as an experimental class while BB class is treated as a control class. To obtain data, researchers conducted observations, interviews with lecturers and students and 
Focus Group Discussion (FGD). This experiment was carried out for 7 times fully online learning with synchronous learning method.

To find out the development of students' English after attending those fully online lectures, the researchers gave a post-test to all students covering four english skills. Both the experimental class and the control class consisted of 24 students. After that the researchers compared the results of the post test conducted in the control class. The following are the results of the effectiveness tests that have been carried out. Meanwhile, the hypothesis in this experiment is summarized as follows:

$\mathrm{H}_{0}$ : There is no difference in the average post-test results between the experimental class and the control class.

$\mathrm{H}_{1}$ : There are differences in the average post-test results between the experimental class and the control class.

\subsubsection{Pre-test Result}

Pre-test was intended to determine the initial ability of all students. The overall score can be seen in the following table. Based on the data obtained, the lowest score in the experimental class was 60 , while the highest score was 87 . The average score obtained was 74.25. Meanwhile in the control class, the lowest score was 60 while the highest score was 85 . The average score of control class was 72.35 as shown in the table 6.

Table 6: Pre-test Result

\begin{tabular}{cccccc}
\hline No & Class & N & Lowest Score & Highest Score & Acerage Score \\
\hline 1 & Experiment & 24 & 60 & 87 & 74.25 \\
\hline 2 & Control & 24 & 60 & 85 & 72.35 \\
\hline
\end{tabular}

Based on the pre-test conducted, the researchers could conclude that ASTRI Budi Luhur students had varied abilities in English. Meanwhile, the average English ability of students in the experimental class and the control class did not differ significantly.

\subsubsection{Post-test Result}

Based on the data obtained, the lowest score in the experimental class was 75, while the highest score was 94 . The average score obtained was 83.46. Meanwhile in the control class, the lowest score was 65 while the highest score was 85 . Meanwhile the average score was 73.71. The overall score can be seen in the table 7.

Table 7: Post-test Result

\begin{tabular}{cccccc}
\hline No & Class & N & Lowest Score & Highest Score & Acerage Score \\
\hline 1 & Experiment & 24 & 75 & 94 & 83.46 \\
\hline 2 & Control & 24 & 65 & 85 & 73.71 \\
\hline
\end{tabular}

\subsubsection{Normality Test}

The next step, the researcher conducted a normality test from the post test score data of the control class and the experimental class that had been obtained. The normality test is carried out using the lilliefors test. Based on the normality test that has been done on experimental class data, $\mathrm{L}_{\text {count }}=0.1423$ and $\mathrm{L}_{\text {table }}=0.176$ at the significance level $(\alpha)=0.05$, for $n=24$. So that the $L_{\text {count }}(0.1423)<L_{\text {table }}(0.220)$, it can 
be concluded that the data is normally distributed. In the control class, $\mathrm{L}_{\text {count }}=0.1099$ and $\mathrm{L}_{\text {table }}=0.176$ at the significance level $(\alpha)=0.05$, for $n=24$. $\mathrm{L}_{\text {count }}(0.1099)<\mathrm{L}_{\text {table }}$ (0.176), it can be concluded that the data are normally distributed. Overall data on the normality test results can be seen in the table 8 .

Table 8: Normality Test

\begin{tabular}{clcc}
\hline No & \multicolumn{1}{c}{ Items } & Experiment Class & Control Class \\
\hline 1 & Average & 83,46 & 73,71 \\
\hline 2 & Standard Deviation & 4,74 & 5,29 \\
\hline 3 & Students & 24 & 24 \\
\hline 4 & L $_{\text {count }}$ & 0,1423 & 0,1099 \\
\hline 5 & L $_{\text {table }}$ & 0,176 & 0,176 \\
\hline 6 & Significance level & 0,05 & 0,05 \\
\hline
\end{tabular}

\subsubsection{Homogeneity test}

Homogeneity test is intended to test whether the data have the same variation or diversity of scores or the same statistics. Homogeneity is a requirement for data to be tested with inferential statistics. Homogeneity test in this study was conducted using the F-Test because both data are independent data. The statistical hypothesis in this homogeneity test is $\mathrm{H}_{0}=$ Homogeneous data $\mathrm{H}_{1}=$ Data is not homogeneous While the testing criteria in this homogeneity test are $\mathrm{H}_{0}$ is accepted if $\mathrm{F}_{\text {count }}<\mathrm{F}_{\text {table }}$ and $\mathrm{H}_{1}$ is accepted if $\mathrm{F}_{\text {count }}>\mathrm{F}_{\text {table. Since }} \mathrm{F}_{\text {count }}=1.25$ and $\mathrm{F}_{\text {table }}=2.01, \mathrm{~F}_{\text {coun }} \mathrm{L}<\mathrm{F}_{\text {table }}$. Thus it was concluded that the data is homogeneous. The entire data can be seen in the table 9.

Table 9: Homogeneity Test

\begin{tabular}{|c|c|c|c|c|c|}
\hline Class & $\mathbf{N}$ & $\mathbf{S}$ & $\mathbf{S}^{2}$ & $\mathbf{T}_{\text {count }}$ & $\mathbf{t}_{\text {table } \alpha} \mathbf{0 , 0 5}$ \\
\hline Experiment & 24 & 4,74 & 22,4330 & 1,25 & 2,01 \\
\hline Control & 24 & 5,29 & 27.9547 & & \\
\hline
\end{tabular}

\subsubsection{Difference Test of Two Averages}

In the next step, the researchers conducted a difference test of two averages that was aimed to test the null hypothesis that there were significant mean differences between the post test results of the experimental class and the control class. In this case, the researchers used t-test. The table 10 are the results of the t-test conducted.

Table 10: T-Test

\begin{tabular}{llllc}
\hline \multicolumn{1}{c}{ Class } & $\mathbf{N}$ & $\mathbf{S}_{\text {gab }}$ & $\mathbf{T}_{\text {count }}$ & $\mathbf{t}_{\text {table } \mathbf{0} \mathbf{0 0 5}}$ \\
\cline { 1 - 2 } Experiment & 24 & 8,38 & 4,03 & 1,68 \\
\cline { 1 - 2 } Control & 24 & & & \\
\hline
\end{tabular}

Based on the table 10, the $\mathrm{t}_{\text {count }}=4.03$, while the $\mathrm{t}_{\text {table }}$ at a 0.05 and $\mathrm{dk} 46=$ 1.68. Thus $t_{\text {count }}>t_{\text {table, }}$ and this means that the $H_{1}$ hypothesis stating that there are differences in the post test scores of students of ASTRI Budi Luhur can be accepted. The average difference indicates an increase in students' English skills after attending lectures with EFS instructional material in full online learning in experimental class. 


\subsection{Discussion}

As stated before that this experiment was carried out for 7 times fully online learning with synchronous learning method. In EFS lectures through Moodle, all students had to $\log$ in on the web page https://elearning.budiluhur.ac.id/. Then, all students had to follow the entire learning cycle carried out in the chat room menu. In general, learning activities were divided into 3 phases: opening, main and closing activities. In the opening phase, the lecturer gave greetings, examined the student presence, asked the students to pray and discussed the goals and objectives of the meeting.

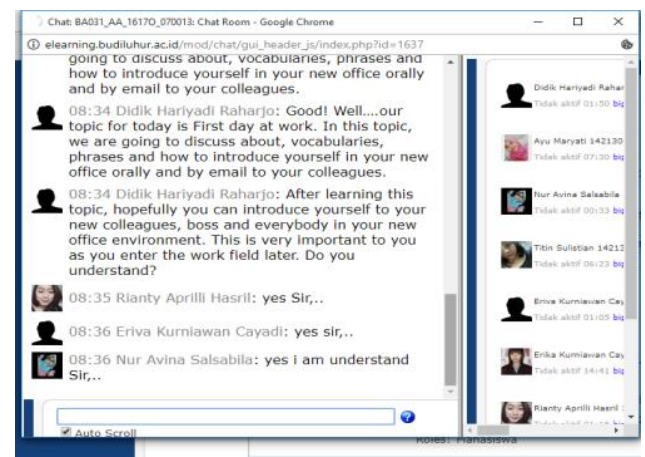

Figure 2: Opening phase

In the main activities, the lecturer checked the students' knowledge about the themes discussed. Then the lecturer asked the students to look for information about the themes discussed from the sources that they had, it could be a book, notes or websites. The next step was, the lecturer invited students to discuss about what they have learned then the lecturer gave an evaluation.

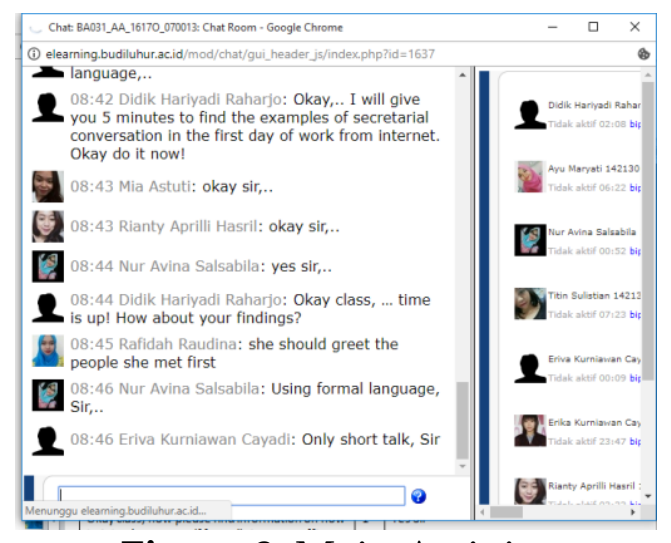

Figure 3: Main Activity

The final phase is closing. In this phase, the lecturer examines student knowledge by giving additional questions and explanations. After that, the lecturer closed the lecture by saying greeting.

After knowing all the lecture activities, here are the materials discussed during the lecture online that have been conducted for EFS course in ASTRI Budi Luhur Jakarta. The first meeting on this experimental test was devoted to discussing the syllabus of EFS courses and lecture contracts for EFS courses. The syllabus has been uploaded to the Moodle e-learning website and could be easily downloaded by students. At this meeting the lecturer discusses the syllabus of each meeting in EFS lectures. In addition, the lecturer also discussed all the rules set forth in the EFS lecture contract. The lecturer also explained about the inquiry learning cycle that will 
be used in EFS learning. The second meeting discussed the theme of "First Day at Work". The material learned by students at this meeting was 3 pieces of listening material entitled: Meeting the H.R., Meeting the colleague, Meeting another colleague. Then students study reading material with the title "Workplace Do's and Don't". The next material was the speaking material with the title "Introduce yourself to your new colleague". While the final material was writing material, in this case, students were asked to make e-mails to introduce themselves to colleagues.

At the third meeting, students learned about "Working with Computer". The materials that had been learned by students at this meeting are: listening with the title "Online Trouble". After that students learned reading text with the title "How to Clean Shortcut virus without Antivirus". The next material was making a process paragraph. The fourth meeting discussed about "Telephoning: Taking and Leaving Messages". At this meeting, students learned listening material with the titles "Leaving Messages" and "Taking Messages". Furthermore, students were asked to make a "telephone log" to record incoming messages by telephone. And the last material was receiving incoming calls. The fifth meeting discussed the theme about "Office Duties and Equipment". In this theme, students learned about office equipment and a secretary's daily activities. The material contained in this theme was listening in the form of video text with the title "The Principal-Agent Problem". The next material was Reading text with the title "A Day in the Life of a Personal Assistant or Secretary". Meanwhile, the last material was writing. In this case students were asked to write their daily activities as a secretary.

At the sixth meeting, students learned about "Inquiry Letter and Reply". On this theme students learned how to make an inquiry letter with replies. The material contained in this meeting was Reading material with some examples of inquiry letters. The next material was writing. In this case students were asked to make an inquiry letter, sent each other to classmates, and then made a reply letter from the inquiry letter received. At the seventh meeting, the theme discussed was "Dealing with Number". The material discussed at this meeting was the listening material. Next is the graphic reading material.

The following is the student presence in EFS course ASTRI Budi Luhur Jakarta by using Moodle in fully online learning:

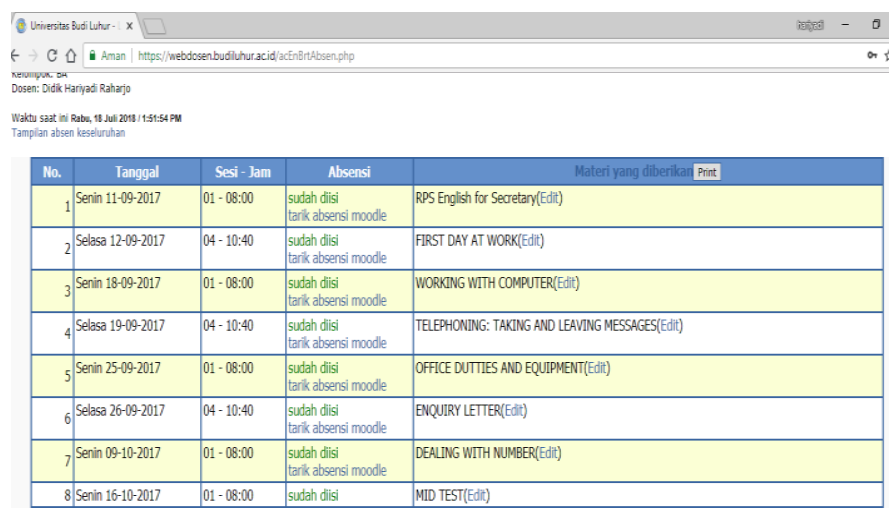

Figure 4: The Student's Presense

Based on the results of the post test conducted, the researcher can conclude that there is an increase in the English language skills of ASTRI Budi Luhur students in four english skills after attending online lectures using EFS instructional material 
through Moodle. This is in line with the findings of research conducted by Irawan \& Surjono, (2018) which showed that students' Listening skills have improved after using Moodle. The effectiveness of the product on learning English in Listening competence is evidenced through the increase in learning outcomes that are known from the percentage of the results of the pretest and post-test evaluation that is equal to $17.19 \%$.

In line with these findings, Castro, (2017) found that the use of attractive, organized and contextual virtual reading worksheets can be useful to improve students' reading comprehension through the adequate use of a set of reading strategies that encourage the development of their vocabulary. In addition, this study shows that Virtual Learning Environments, such as Moodle, provide significant opportunities for students to empower their language learning processes, which in this case, are aimed at reading comprehension.

Furthermore, Elhawwa, (2017) stated that the various features provided by Moodle are very useful for learning English. In addition, Moodle provides space for students and lecturers to interact with each other. In this case, Moodle is used as supplementary or supplementary instructional material after classroom learning. Feizabadi \& Ahmadabad (2016), in their research found that students who study English through Moodle obtain significantly better results than conventional classes. Gunduz \& Ozcan, (2017) conducted a perception test on the use of Moodle in learning English to 333 students and 12 lecturers. The results showed that students generally considered that Moodle was quite useful in learning English while the lecturer said that Moodle was contemporary and beneficial in the long term but at that time did not function optimally.

Meanwhile, Khabbaz \& Najjar, (2015) stated the different findings that indicated that language learning through Moodle-based instructional material hindered the process of becoming an autonomous language learner, which was a prerequisite for language learning in remote contexts.

\section{Conclusion}

Based on the explanation above, it can be concluded that Moodle provided various features that are used to develop English instructional material for the secretary which includes 4 language skills (listening, reading, speaking and writing). By using Moodle, the students and lecturer interactions could run well through the chat room module. In this module, the lecturer could provide an explanation and students could ask if they faced some difficulties. Furthermore, based on the results of the post test conducted, EFS instructional material through Moodle had been proven to be able to improve four english skills which include listening, reading, speaking and writing to the students of ASTRI Budi Luhur Jakarta. The result of this research implied that Moodle was an effective platform used in the development of English instructional material. The limitation of this research was that the developed instructional material are only implemented at Budi Luhur ASTRI because of the limited of time and cost required in this research. For this reason, the future research should be able to further explore the modules provided by the Moodle platform for the development of instructional material and English teaching learning process. 


\section{Acknowledgments}

The researchers would like to thank to all those who have helped in completing this research. The researchers thank to Budi Luhur Cakti Education Foundation Jakarta for all funding support in this research. Acknowledgments were also given to all management and students of ASTRI Budi Luhur Jakarta, who have helped the researcher in completing this research.

\section{References}

Arifin, Z. (2012). Penelitian Pendidikan Metode dan Paradigma Baru. In Rosdakarya. https:/ / doi.org/10.1016/S0969-4765(04)00066-9

Bader Al Bataineh, K., Abdullah Ahmed Banikalef, A., \& H. Albashtawi, A. (2019). The Effect of Blended Learning on EFL Students' Grammar Performance and Attitudes: An Investigation of Moodle. Arab World English Journal. https:/ / doi.org/10.24093/awej/vol10no1.27

Castro, K. R. (2017). Moodle-Based Worksheets to Enhance Reading Comprehension. https:/ / doi.org/-

Cedar, P. (2013). EFL Online Learning versus Classroom Learning by Thai Students, The Asian ESP Journal. Volume 9 Issue 1, 28-53

Cordova, J. V., \& Dechsubha, T. (2018). Using moodle in improving listening abilities in english for specific purposes of vongchavalitkul university students. Asian ESP Journal.

Darmawan, D. (2014). Pengembangan E-LEARNING Teori dan Desain. In Remaja Rosdakarya. https:/ / doi.org/Bandung: PT. Remaja Rosdakarya

Eamjoy, A., (2015). Astudy of needs and barriers in english communication skills of thai secretaries at the women secretaries and administrative professionals association of Thailand (WSAT) . Master of Arts English for Careers Language Institute. Thammasat University. Bangkok

Elhawwa, T. (2017). The implementation of Moodle platform through lecturer's perspectives at English department. Journal on English as a Foreign Language, 7(2), 227. https:// doi.org/10.23971/jefl.v7i2.502

Gluchmanova, M. (2017). Creation of e-courses in english for students of production technology. TEM Journal. https:/ / doi.org/10.18421/TEM63-25

Gunduz, N., \& Ozcan, D. (2017). Implementation of the Moodle System Into EFL Classes. Profile: Issues in Teachers' Professional Development. https://doi.org/10.15446/profile.v19n_sup1.68571

Irawan, R., \& Surjono, H. D. (2018). Pengembangan e-learning berbasis moodle dalam peningkatkan pemahaman lagu pada pembelajaran bahasa inggris. Jurnal Inovasi Teknologi Pendidikan. https:// doi.org/10.21831/jitp.v5i1.10599

Khabbaz, M., \& Najjar, R. (2015). Moodle-based distance language learning strategies: An evaluation of technology in language classroom. International Journal of Applied Linguistics and English Literature. https:/ / doi.org/10.7575/aiac.ijalel.v.4n.4p.205

Noirid, Surachet; Srisa-ard, B. (2007). E-learning Models: A Review of Literature. The 1st International Conference on Educational Reform.

Nurhayati, D. (2013). The Development of Moodle Based English Reading Material, Language Circle Journal of Language and Literature Vol. VIII/1,35-43 
Didik Hariyadi Raharjo, Ilza Mayuni, Emzir: Improving the Students' English Skills...

Porter, P. A., \& Brown, D. (1997). The Elements of Language Curriculum: A Systematic Approach to Program Development. TESOL Quarterly, 31(4), 814. https:/ / doi.org/10.2307/3587769

Richards, J. C., \& Rodgers, T. S. (2001). Approaches and Methods in Language Teaching. In Approaches and Methods in Language Teaching. https://doi.org/10.1017/cbo9780511667305

Richards, J. C., \& Schmidt, R. (2010). Longman dictionary of language teaching \& applied linguistics. In Proceedings of the 21st Asian Pacific Weed Science Society (APWSS) Conference, 2-6 October 2007, Colombo, Sri Lanka.

Robertson, C. E. (2008). Integration of moodle course management system (CMS) into an EFL writing class. The JALT CALL Journal,.

Stanford, J. (2009). Moodle 1.9 for second language teaching: Engaging online language-learning activities using the Moodle platform. In Language Teaching.

Tomlinson, B. (2011). Introduction: principles and procedures of materials development. In Materials Development in Language Teaching.

Toselli, M \& Milan, A.M. (2006) English for Secretaries and Administrative Personnel. New York: McGraw-Hill

Wade, J. C. (2018). Towards Autonomy in Language Learning: Theoretical Implications and Practical Applications. Verbum. https:/ / doi.org/10.15388/verb.2017.8.11335 